\title{
An Evaluation of Digital Stories Created for Social Studies Teaching
}

\author{
Burcu Sezginsoy Şeker \\ Necatibey Education Faculty, Balıkesir University, PO box 10100, Balıkesir-Altı Eylül, Türkiye
}

\begin{abstract}
Absract
Digital stories are useful tools for combining technology with education, in terms of the preparation stage, practicality, availability and usability as an evaluation instrument. In this study, digital stories created in a social studies teaching class were evaluated and the opinions of primary school teacher candidates were obtained concerning the digital stories they created. The study group consisted of 35 teacher candidates studying in the 3rd grade of the Primary School Teaching Department, Necatibey Faculty of Education, Balıkesir University. In this study, the case study method was used and both qualitative and quantitative data were also included to further investigate the subject. The Digital Story Evaluation Scale and Semi-structured Interview Form were used for collecting data. After implementing the Digital Story Evaluation Scale an Individual Performance Grade (IPG) was created to evaluate the individual performances of the teacher candidates. As a result of the data analyses, the difficulties encountered in the digital story creation process were studied after they had been divided into six categories, including the audio record not working simultaneously with the images, not being able to create an ideal scenario, not being able to find an appropriate image for the scenario, audio disconnection during image transition, difficulties in finding background music, and difficulties in using the programme.
\end{abstract}

Keywords: digital story; social studies teaching; primary school

\section{Introduction}

We are witnessing a century where information and communications are rapidly developing, and technological products are constantly being updated. As life in 21 st century is facilitated by the influence of rapidly developing technological products, the qualifications we need to access to this facility are also increasing. Today's children are growing up with the PC, the Internet, mobile phones, cameras and all the other products of the digital world. These children, called "digital natives" by Prensky (2001), perceive the world in a different way, think multidimensionally, make decisions more quickly and bring technological products into the center of their lives. PC games, e-mail, the Internet, mobile phones and text messages have become an indispensable part of these students' lives (Prensky, 2001). Considering all these, in technical terms, today's teachers also need to have specific qualities. This is because the technology has a significant place in maintaining educational progress and as a result educators are required to combine their own area of study with technology (Akkoyunlu, 2002). Digital stories can be used when integrating technology into the classroom environment. The digital world provides opportunities for the teachers to create an educational environment for the digital natives. The digital story is an educational tool that is revealed when the participants convey a story from their own lives to the digital environment, by supporting it with their own voice and their choice of visual images. Digital stories can be used to diversify the learning experiences in today's classroom environments, where the use of technology has become a necessity. As a new method, digital storytelling can be used to improve the students' skills for the current age, encourage them and increase their motivation to learn (Morgan, 2014). Digital storytelling offers several opportunities for teachers giving lessons and for their students listening to them. The most important aspect of this kind of storytelling is that, unlike traditional stories, it is repeatedly accessible in a multimedia and with a multiperspective (Hess, 2014). From another perspective, students who are active in the digital story writing process can make use of their skills in a versatile manner both as an author and editor, as well as a producer and actor. Teachers are considered as the instructor, guidance, checkpoint and planner of this whole process.

\subsection{Digital Storytelling}

Digital storytelling is a concept that emerged in the early 1990's. It is considered that the emergence of the Center for Digital Storytelling, created by Joe Lambert and Dana Atchley, was to provide assistance and training to people 'interested in creating and sharing their personal narratives.' Another objective of the Center for Digital Storytelling has been to develop and disseminate the seven elements of effective digital storytelling (Robin, 2006; 2008, p. 222). All elements of this process first need to be addressed in order to understand the digital area, which is a new and dynamic area in storytelling. Joe Lambert set out the Seven Elements of Effective Digital Stories as follows: 1. Showing the author's perspective 2. Finding a compelling question at the end of the story, 3. Maintaining a personal and powerful approach to the story 4. Providing good audio to help understand the content of the story, 5. Using the power of music to support the storyline, 6. Being economical in telling the content of the story, 7. Ensuring the slow or quick progression of the story (Robin, 2006). 
According to İnceelli (2005), there are five elements that make up digital stories, and these are listed as: media, mobility, relationship, context and communication. These have been detailed as classifying digital stories, analyzing the content of the existing practices, and measuring the appearance of various forms of digital stories and their impact on the audience. When considering this classification, digital storytelling is the process by which a narrative is presented and includes elements such as, information, education and entertainment. The purposes are based on multimedia applications, such as audio, picture, graphics, sprite graphics, image, music, text, photo, and animation, as well as the narrator's own voice. This makes the user active by providing them with the control of an interactive, digital environment; ensures that they discover and create information on their own and use this information in real life situations; provides that the user form the information in their mind in a meaningful way for themselves while moving through the storyline and reinforce it with exercises and practices (İnceelli, 2005).

Sylvester and Greenidge (2009) list the steps for the process by which digital story narratives are created, as follows:1. Writing a story,2. Sketching the story on a storyboard matching with the narration.3. Numbering sections of text 4. Creating graphics that complement the scenes, such as photographs and clip art.5. Audio recording the narration.6. Combining the files in a movie into the existing story with a video-editing program, such as Movie Maker or iMovie.7. Adding a title frame.

Based on the research, it is possible to say that creating digital stories is a planned process with stages, which is open to change, can be stored in the digital media, turned into different forms for new uses, where sound and image are matched to suit the purpose, and that can be adapted for personal, real life situations, and presented in the digital media. This process starts with the steps of expressing an opinion, choice of content and sketching, just like the traditional story writing process. After the sketching step, the student can create a story map or table to visualize the story. Here, students need to plan which multimedia tools they will use and how to make use of these to present an instructive, interactive and significant story (Chung, 2007, p.18). Students who complete the planning stage pass on to the production stage. This stage is undertaken in the computer lab to combine the sounds, records and the images. These processes can be completed by using computer programmes such as Movie Maker, iMovie or Photostory3.

\subsection{Digital Storytelling in Education}

The creation of digital stories starts with the selection of an appropriate subject. Three main titles can guide the authors in the selection of subject. These titles can be listed as follows:1. Personal Narratives that speak of personal experiences, memories, events and life stories, which constitute the most commonly used story narratives.2. Historical Documentaries, where historical speeches and images from famous events are used to reexamine them in the digital media.3. Stories that Instruct, which are prepared to instruct or inform a target audience about a particular subject. After selecting any of these titles, writing the text can begin. (Kurudayığlu \& Bal, 2014). The title frequently used by teachers in the process of creating educational digital stories is, 'Stories that Instruct.' Within the framework of this title, subjects in the curricula can be transformed into stories that reinforce learning. Historical documentaries or personal narratives can also be used to attract the attention of the students or form new opinions about them. These titles, which constitute the subjects of digital stories, can be turned into potent teaching tools depending on the way the content is explained.

The use of digital storytelling in education also increases research-based learning skills for students who are thinking about creating their own stories. Educators can show the digital stories that they have made as an example for students who are planning to create their own. After viewing the examples stories, students can be given assignments in which they are first asked first to research a topic. Then, they will be expected to select an appropriate title of their own (Robin, 2006). Within the scope of the chosen title, work based on the information is carried out while taking into consideration the seven elements of digital storytelling. It will be explained to the students how to use programmes such as Movie Maker, iMovie or Photostory3, which will help with the preparation of these elements. In the ensuing process, the students' motivation, creativity and research skills will be prioritised. Students who create, tell and convey their own stories will also have the opportunity to become more self aware. This concept of realisation will include their success in telling their stories, their communication skills being open during editing, learning to organise their opinions, showing their skills to reflect their thoughts in the story, and developing their presentation talents. In cases where stories are prepared in groups, students will have a collaborative and coordinated study environment and have the opportunity to share their work with their peers.

Barrett (2006), who asserted that digital storytelling should be used in education, claimed that digital storytelling combines and facilitates student engagement, reflection for deeper learning, project-based learning and technology integration strategies. Digital stories also support various alternatives, including individual, project-based, collaborative learning, with the active student engagement, as part of various learning strategies (Robin, 2006; Sadik, 2008; Sylvester \& Greenidge, 2009; Yüksel, 2011). Similarly, Alexander (2011) claimed that the process of creating a digital story can be group-based and be helpful in implementing collaborative 
learning to the students. According to Smeda, Dakich \& Sharda (2014), digital stories are an efficient pedagogical tool that increases the motivation of students, while providing a learning environment for the students in the process of story creation through collaboration, reflection and interpersonal communication.

With the use of digital storytelling in education, a link was established between new generation students who are integrated with the technology and traditional school environment (Ohler, 2013). Also, digital stories can be used in increasing the motivation of the students, in particular, to read and write, allowing them to personalize the learning experience, making students gain in-depth and meaningful reading experiences, and providing them with information and skills about the technical aspects of language (Ohler, 2013; Ware \& Warschauer, 2005). Digital storytelling provides several potential learning benefits, including increasing the motivation of the student, making it a perfect strategy that needs to be taken into consideration to make use of it in personal storytelling (Miller, 2009). This strategy helps the students exhibit a witty and different understanding of the world (Hull, 2003).

Although digital story work is generally associated with the art and human sciences, it can be used as an effective tool in different classes and several fields, such as history, reading, writing, and physical sciences (Sadik, 2008). Inclusion of digital stories as a complementary tools to the curricula can contribute to effective teaching and learning (Smeda et al., 2014). Digital stories also help concretize abstract concepts, transform conceptual content in a more understandable way as well as conveying content in an interesting way (Robin, 2006). Social sciences is a discipline that, due to its nature, includes many abstract concepts. Use of digital stories in social sciences teaching is considered to be an effective way of concretizing abstract concepts, increasing continuance in learning thanks to its appeal to multiple senses, and developing creative thinking. In this context, the study has shown that primary school teacher candidates were first taught the effective digital story creating steps, then prepared their own stories, to dynamise the social sciences class, and finally shared their practices and made an evaluation. In this study, digital stories created by the primary school teacher candidates were evaluated and their opinions on the digital stories they created were obtained. The study sought to answer the following research questions:

1. How were the digital stories created by the primary school teacher candidates evaluated?

2. What are the opinions of the primary school teacher candidates concerning digital story creation?

\section{Method}

The case study method was used for this study. Case studies provide rich, deep and explanatory information about the subject that is being researched. Such studies can be used to closely examine people, topics, issues or programmes (Hays, 2004). It is thought that with this research method, more detailed information can be obtained about the creation of digital stories that can be used in the teaching of social studies. Also, both qualitative and quantitative data were used to analyze the results in further detail.

\subsection{Study Group}

The study group consisted of 35 teacher candidates studying at the 3rd grade of Primary School Teaching Department, Necatibey Faculty of Education, Balıkesir University, in the second semester of the 2014-15 academic year. This study was undertaken as part of the social studies teaching class and a simple, random sampling method was used in determining the study group. The main concept in this sampling method is that all elements in the universe have an equal and independent chance to be selected as a sample (Büyüköztürk, KılıçÇakmak, Akgün, Karadeniz \& Demirel, 2010, p.84). Following an informative study relating to the process of creating a digital story, randomly selected teacher candidates were selected for inclusion in the study.

\subsection{Data Collection Tools}

The Digital Story Evaluation Scale was used in this study. The scale was prepared for undergraduate students by Barrett (2010) and used as an evaluation scale at Houston University. The feature of this scale is that it was designed for the evaluation of semester-long projects that bring together all the steps for creating a digital story, including selecting a topic, conducting research, writing a script, recording audio narration, and collecting and creating images. The scale consists of seven points and includes five categories to answer. These categories are evaluated by scores between 0-4. Different scores and comments are given for each item. The maximum value that students can receive at this scale that consists of seven points is 28 . These points can be summarised, as the purpose of the project, quality of the text, quality of audio narration, quality of the photos, use of proper digital images, fitness of the softwares used, and choice of proper content, respectively.

The reliability of the digital story evaluation scale was reviewed by calculating the agreement percentage of the scoring. Kappa statistics were used to determine the agreement between the evaluations of two or more observers. The Kappa coefficient varies between -1 and +1 . A score of zero represents chance agreement; negative values represent a worse agreement than chance, while a score of +1 represents excellent agreement. A Kappa coefficient between .40 and .75 is a reasonable agreement. If it is greater than .75 , then it is an excellent 
agreement (Şencan, 2005, p.265-267). That is why, in this study, the Cohen Kappa coefficient was calculated to determine the reliability of the scale. The following agreement percentages have been reached regarding the reliability of the seven points of the scale. The Cohen Kappa coefficient was calculated for the agreement between the evaluation results of the researchers and is composed of the participants to the pilot study including a total of 20 primary school teacher candidates studying at the Necatibey Faculty of Education, Balıkesir University.

The results were as follows: $\mathrm{K}_{\text {purpose }}=.74, \mathrm{~K}_{\text {text }}=.41$ and $\mathrm{K}_{\text {audio narration }}=.69, \mathrm{~K}_{\text {photos }}=.43, \mathrm{~K}_{\text {digital images }}$ $=.50, \mathrm{~K}_{\text {software, }}=.70$ and $\mathrm{K}_{\text {content }}=.48$ These values indicate that there is reasonable agreement between the observers. In this case, it is possible to say that the scale is reliable.

In order to find an answer to the question, "What are the opinions of the primary school teacher candidates related to digital story creation?", the opinions of the primary school teaching students on the process of creating a digital story and afterwards were obtained using a semi-structured interview. Instructors studying at the department of primary school teaching and curriculum were asked for their opinions to ensure the content validity of the interview form. The points comprising the interview form were organised in accordance with the expert opinions and the aim of the study. In this context, three interview questions were determined. These questions are the difficulties encountered during the process of creating digital stories, the contribution made by the digital story to learning and the contributions that digital story creation could provide for primary school teachers.

\subsection{Data Collection Process}

The duration of this study as part of social sciences teaching class was determined to be 14 weeks. During the first week, an informative study was carried out by the researcher about the digital storytelling process. This included a definition of the digital story, the types of digital stories and the seven elements of effective digital stories. During the second week, Windows Movie Maker and Photo Story 3 programmes were introduced to help create digital stories. In the third week, digital stories were addressed in the class and the choice of topic among the primary school 4th grade social sciences class, attainments and the reasons for choosing those topics, were described by the students. In the fourth week, suitable scenarios were drawn up and the scenarios were shared and discussed in the class. For the fifth week, images related to the scenarios were researched, images that could not be found were created, and appropriate background music was selected for the scenario. During the sixth week, the audio recordings were prepared by the students and the harmonizing of the music with the scenario were listened to and discussed online. During the rest of the weeks, 3-5 minute digital stories of the students were watched online, and the other students commented on each digital story video. The researcher chose 20 digital stories using a simple, random sampling method for the pilot implementation of the study. The main implementation included 15 digital stories and teacher candidates. The selected digital stories were evaluated by using a digital evaluation scale. The individual performance grades of the primary school teaching students were presented. Following the implementation, primary school teaching students were asked for their opinions regarding digital story creation using a semi-structured interview.

\subsection{Data Analysis}

After implementing the digital story evaluation scale, an individual performance grade (IPG) was created to evaluate the individual performances of the teacher candidates. Bukova Güzel and Uğurel's (2010) study was used in the preparation of the individual performance grades. In this context, a 5-point scoring system (0-4) was used, as also shown in the scale. Table 1 illustrates how this scoring system is used in each step. In this scoring system, a score of 0 is given for no approach, while showing a desired approach in real terms indicates a score of 4.

According to the 5-point (0-4) scoring system, the total scores of the students in each step of the 7-point scale for all students individually were defined as an individual performance grade. Individual calculations were made for each of the scale points for each teacher candidate, and their performance on one point in terms of all categories was shown. The results of the primary school teacher candidates participating in the digital storytelling project were analyzed according to four categories: unsatisfactory, moderate, successful and very successful. The points that were taken into consideration while creating these four categories are listed below.

Number of scale points is 7 . The highest scores to have for each point is 4 , while the lowest is 0 . The highest score a teacher candidate can receive for all points is 28 , while the lowest is 0 .

Unsatisfactory includes scores between 0-13.9. A person who has a score of 1 for each of the points on the scale will have an individual performance grade of 7 and it will be considered as unsatisfactory. A person who has more than a score of 2 for each point will have an individual performance grade of 14 and there will be no change in the performance of this person. Therefore, the upper limit for unsatisfactory individual performance grades is set to 13.9 .

Moderate includes scores between 14-17.4. An average of 2 will require a change of performance. It is 
because this situation requires a score of 1 as well as 2 for the total. In this case, the lower limit of 14 is reached. While determining the upper limit, it is seen with the same approach that an average of 2.5 will require a change of individual performance grade and thus 17.4 should be the upper limit.

Successful includes scores between 17.5-24.4. An average of 2,5 will, again, require a change of performance. It is because this average requires a score of 2 as well as 3 . Thus, the lower limit was determined as 17.5 by multiplying 2.5 by 7 . The upper limit is 28 .

Very Successful includes scores between 24.5-28. An average of 3,5 will, again, require a change of performance. It is because this average requires a score of 3 as well as 4 . Thus, the lower limit was determined as 24.5 by multiplying 3.5 by 7 . The upper limit is the highest total score of 28 .

The answers given for the points on the interview form were described in-depth (by using content analysis), analyzed, and turned into appropriate themes. Similar expressions for the answers were listed and then it was determined how often they used it. The codes that were presented later were grouped under common titles. Direct quotes were included in order to reflect the perspectives of the interviewees and to allow for the situation to be pictured by the reader in a clearer way. As a result of the data analyses, the difficulties encountered in the digital story creation process were studied after they had been divided into six categories, including the audio record not working simultaneously with the images, not being able to create an ideal scenario, not being able to find an appropriate image for the scenario, audio disconnection during image transition, difficulties in finding background music, and difficulties in using the programme. When the answers to the question "How is the contribution of the use of digital stories to learning" are analyzed, it was shown that use of digital stories contribute in 4 categories in total including active engagement, lasting learning, drawing attention, and learning by concretizing. Primary school teaching students have reached a consensus that creating a digital story can contribute to primary school teachers in 5 areas in total. These areas include facilitating expression, efficient use of the learning time, summarizing the topic, providing technological information, and developing creative ideas.

Table 1. A Section of the scoring key used in evaluating digital story scale.

\begin{tabular}{|c|c|c|c|c|c|}
\hline $\begin{array}{c}\text { Digital } \\
\text { storytelling } \\
\text { project }\end{array}$ & $\begin{array}{c}\text { Excellent } \\
\text { (4 points) }\end{array}$ & $\begin{array}{c}\text { Good } \\
(3 \text { points })\end{array}$ & $\begin{array}{c}\text { Fair } \\
(2 \text { points })\end{array}$ & $\begin{array}{c}\text { Poor } \\
\text { (1 points })\end{array}$ & $\begin{array}{c}\text { No score } \\
(0 \text { points })\end{array}$ \\
\hline $\begin{array}{c}\text { 1. Purpose of } \\
\text { the project }\end{array}$ & $\begin{array}{c}\text { Establishes a } \\
\text { purpose early on } \\
\text { and maintains a } \\
\text { clear focus } \\
\text { throughout. }\end{array}$ & $\begin{array}{c}\text { Establishes a } \\
\text { purpose early on } \\
\text { and maintains } \\
\text { focus for most of } \\
\text { the project. }\end{array}$ & $\begin{array}{c}\text { There are a } \\
\text { few lapses in } \\
\text { focus, but the } \\
\text { purpose is } \\
\text { fairly clear. }\end{array}$ & $\begin{array}{c}\text { It is difficult to } \\
\text { understand the } \\
\text { full purpose of } \\
\text { the project. }\end{array}$ & $\begin{array}{c}\text { No purpose is } \\
\text { included or the } \\
\text { project was not } \\
\text { submitted. }\end{array}$ \\
\hline
\end{tabular}

\section{Results}

The data acquired from the study were analyzed using quantitative and qualitative techniques. Quantitative data were reviewed by descriptive statistics and qualitative data by descriptive analysis. Results were presented in 2 categories: 1. Results on performance evaluations, 2 . Results on individual evaluations.

\subsection{Results on Performance Evaluations of the Students}

Findings on the digital story projects prepared by the students were evaluated by using a "Digital story evaluation scale". The results are given in Table 1. These results were evaluated by using a 5-point scoring system (0-4), as also shown in the scale. The results of the primary school teacher candidates participating in the digital storytelling project were analyzed according to four categories: unsatisfactory, moderate, successful and very successful. According to the results in Table 1,9 of the primary school teaching students participating in the study had a very successful, 2 had a successful, 3 had a moderate and 1 had an unsatisfactory project. When individual averages for each of the scale points are considered, it is seen that the highest average is "purpose of project" with an average of 3.86. In this case, it can be inferred that the students established a purpose for their digital story projects from the beginning and followed it until the end. Weekly evaluation works with the students and creating a discussion environment to ensure that works are carried out according to the purpose of project can be shown as one reason for not deviating from the purpose of project. The point with the lowest average in the scale was 'Quality of Audio Narration, ease of hearing; if any, volume of the added music and its relevancy to the content of project' with an average of 2.86. Audio narration was carried out in an appropriate environment determined by the students. When the projects were examined, it was seen that some of the students had received help from their friends for the audio narration. In this context, it is seen that accentuation was not made while explaining the scenario and the volume was low. Also, the fact that the background music was not added at the correct level and that it drowned the voice-overs are considered as the shortcoming of the project. Another problem regarding the voice-overs is that the audio recordings do not work simultaneously with the images. The primary school teaching students were not able to successfully carry out the timing simultaneously. Audio disconnection during visual transitions can be associated with the moderate use of digital 
image editing softwares. This can be seen as the reason for the fifth point of the evaluation scale to be the second lowest average by 3.13. Another issue regarding the fifth point, "Creating the project by a digital image editing software and including improved digital images," is that some students experience dithering in the images while preparing their project. This negatively affected the quality of the project images. When the average of the scale points were considered, the second highest average was for Good text writing; establishing a meaningful purpose for the story and maintaining consistency until reaching a reasonable conclusion by the end of the story with an average of 3.46. It is possible to say that the written scenarios were prepared according to fourth grade level. Also, protagonists were used in some projects to attract the attention of the students and to increase the memorability of the story. This resulted in the scenario being effective. The protagonists were sometimes supported by storybooks or web-based images, and the students made drawings relating to the scenario when they could not find proper images. This positively affected the success of the project

\subsection{Results on Individual Evaluations of the Students}

The following questions were addressed at the students to analyze the opinions of primary school teaching students on digital story creation

1. What are the difficulties that you have encountered during the process of creating a digital story?

2. What is the contribution made by digital stories to learning?

3. What are the contributions that digital story creation could provide for primary school teachers?

As a result of the data analyses, the difficulties encountered in the digital story creation process were studied after they had been divided into six categories, including the audio record not working simultaneously with the images, not being able to create an ideal scenario, not being able to find an appropriate image for the scenario, audio disconnection during image transition, difficulties in finding background music, and difficulties in using the programme. Table 2 includes this category and the opinions of teacher candidates.

Table 2. Categories for the opinions on the difficulties encountered during the process of creating digital stories

\begin{tabular}{|c|c|c|}
\hline Categories & $\begin{array}{l}\text { Frequency } \\
\text { (f) }\end{array}$ & Opinions \\
\hline $\begin{array}{l}\text { 1. Audio recording not } \\
\text { working simultaneously } \\
\text { with the images }\end{array}$ & 3 & $\begin{array}{l}\text { PST2. While preparing my digital story we had a hard time to take the } \\
\text { images, recording the audio, and then preparing the audio record } \\
\text { according to the image. I had difficulty in matching the audio record } \\
\text { with the image. I tried to arrange the timing by recording the audio } \\
\text { over and over but this was a little hard for me. }\end{array}$ \\
\hline $\begin{array}{l}\text { 2. Not creating a } \\
\text { scenario that fits the } \\
\text { attainment }\end{array}$ & 4 & $\begin{array}{l}\text { PST12. I spent a long time creating the scenario for the story to fit the } \\
\text { attainment level of the students, and for the students to understand the } \\
\text { message given. }\end{array}$ \\
\hline $\begin{array}{l}\text { 3. Not finding an image } \\
\text { that fits the scenario. }\end{array}$ & 12 & $\begin{array}{l}\text { PST6. I prepared my digital story using the fresh paint programme. I } \\
\text { prepared a page for each section of my story by creating a background } \\
\text { colour on Paint. I created virtually everything I could draw on Paint, } \\
\text { such as trees, houses, and birds. Those I could not draw I found on the } \\
\text { Internet. The background, images on PowerPoint and screenshot... It } \\
\text { was hard for me to prepare a background for each stage and find a } \\
\text { picture. It was really hard to do it on the Internet, but this was my } \\
\text { choice. I preferred it [this way] so that it would be more convincing } \\
\text { and colourful. Voice-over and adjusting the sound during image } \\
\text { transitions was also hard. }\end{array}$ \\
\hline $\begin{array}{l}\text { 4. Audio disconnection } \\
\text { during image transitions }\end{array}$ & 3 & $\begin{array}{l}\text { PST4. While creating my story, the audio cutting off during transitions } \\
\text { and disconnecting between images gave me a hard time. }\end{array}$ \\
\hline $\begin{array}{l}\text { 5. Difficulties in finding } \\
\text { the background music. }\end{array}$ & 2 & $\begin{array}{l}\text { PST11. I had difficulty in creating a text that fitted the attainment level } \\
\text { and enriching it with images. I also had a hard time in finding and } \\
\text { downloading the background music. }\end{array}$ \\
\hline $\begin{array}{l}\text { 6. Difficulties in using } \\
\text { the programme }\end{array}$ & 3 & $\begin{array}{l}\text { PST10. We were introduced to a new programme but we had difficulty } \\
\text { in understanding and learning it. }\end{array}$ \\
\hline
\end{tabular}

According to the opinions of primary school teaching students, "Not finding an image that fitted the scenario" was found to be the most common difficulty during the process of creating a digital story. The reason for this can be seen as the tendency of primary school teaching students, who create a scenario that fits the attainment, only to search online for the images for the level of primary school students. Another problem encountered during the process is "not creating a scenario that fits the attainment". It was an anticipated situation, expressed by four students for this problem. "Good text writing, establishing a meaningful purpose for the story and maintaining consistency until reaching a reasonable conclusion by the end of the story", another point that is included in the digital story evaluation scale, showed that the same students scored 2 or 3 . In this context, it is 
possible to say that the students who had difficulty in creating a scenario that fit the attainment were also unsuccessful in finding a meaningful purpose for their text and maintaining this consistency. Other situations described in the process of creating a digital story included, "audio record not working simultaneously with the images", "audio disconnection during image transitions" and "difficulties in using the programme." Audio disconnection during the image transitions were associated with the students' intermediate level when using the digital image editing software. "Difficulties in finding background music" was found to be the least difficult situation for the primary school teaching students during the process of creating a digital story. This indicates a contrast with the digital story evaluation scale findings. This is because the scale point with the lowest average in the project evaluation scale was found to be "Quality of audio narration, ease of hearing; volume, if any, of the added music and its relevancy to the content of the project" with an average of 2.86. Even though the students saw themselves capable of finding background music, the fact that the music in the background was not added at the correct level and that it drowned voice-overs were considered as the shortcomings of the project.

When the answers to the question "How is the contribution of the use of digital stories to learning" are analyzed, it was shown that use of digital stories contribute in 4 categories in total including active engagement, lasting learning, drawing attention, and learning by concretizing. Table 3 includes this category and the opinions of teacher candidates.

Table 3. Categories for the opinions on the contribution of the use of digital story to learning

\begin{tabular}{|l|l|l|}
\hline Categories & Frequency (f) & Opinions \\
\hline $\begin{array}{l}\text { Enctive } \\
\text { Engagement }\end{array}$ & 4 & $\begin{array}{l}\text { PST6. The story that we prepared can be used a teaching technique in a } \\
\text { classroom environment. Plain narration would be too boring. Children } \\
\text { would be more interested in the lesson when it appeals to their world. They } \\
\text { cannot just listen, but they also need to actively engage. }\end{array}$ \\
\hline $\begin{array}{l}\text { Leasting } \\
\text { Learning }\end{array}$ & 12 & $\begin{array}{l}\text { PST4. Since our audience is in their concrete operations stage, I think that } \\
\text { they will learn in a much more lasting way by seeing and hearing. Also, } \\
\text { children like these kind of things. It is more logical to support the topic with } \\
\text { a video rather than lecture for hours. }\end{array}$ \\
\hline $\begin{array}{l}\text { 3.Drawing } \\
\text { Attention }\end{array}$ & 9 & $\begin{array}{l}\text { PST8. Digital stories help a great deal in terms of attracting attention and } \\
\text { listening with interest to the story. }\end{array}$ \\
\hline $\begin{array}{l}\text { 4.Learning by } \\
\text { Concretizing }\end{array}$ & 3 & PST13. It can facilitate learning by concretising abstract topics. \\
\hline
\end{tabular}

When the opinions of primary school teaching candidates are sought, it is seen that the area which the use of digital story contributes most to learning is "lasting learning". This is described by primary school teaching students as being the "digital story creation process allows more senses to be active "in learning, leading to lasting learning". Another area that use of digital story contributes to learning is considered to be "drawing attention". Primary school teaching students have said that they can use digital stories, particularly while teaching social studies, as a tool to "attract attention" at the introduction of the class. Another area that is considered to help learning is "active engagement". Digital story creation is thought of as a process in which primary school teaching students can actively participate in learning. The area with the least contribution is claimed by the students to be "learning by concretizing".

Primary school teaching students have reached a consensus that creating a digital story can contribute to primary school teachers in 5 areas in total. These areas include facilitating expression, efficient use of the learning time, summarizing the topic, providing technological information, and developing creative ideas. 
Table 4. Categories for the opinions concerning contributions made suggesting that digital story creation could provide for primary school teachers.

\begin{tabular}{|l|l|l|}
\hline Categories & Frequency (f) & Opinions \\
\hline $\begin{array}{l}\text { 1.Facilitating } \\
\text { Narration }\end{array}$ & 4 & $\begin{array}{l}\text { PST6. A topic that is boring and difficult for the teacher to tell can be } \\
\text { told more easily through digital story. }\end{array}$ \\
\hline $\begin{array}{l}\text { 2. Effective use of } \\
\text { learning time }\end{array}$ & 2 & $\begin{array}{l}\text { PST13. It can be helpful for the teacher in terms of using the time more } \\
\text { efficiently. It is because the digital story can both be used as an } \\
\text { introduction and also as a summary. }\end{array}$ \\
\hline $\begin{array}{l}\text { 3.Summarizing the } \\
\text { topic }\end{array}$ & 4 & $\begin{array}{l}\text { PST4. It makes the job of the teacher easier. Words are abstract, making } \\
\text { it hard for the student to understand. The teacher will need to expend } \\
\text { more effort while teaching. As a result, in education the principal of } \\
\text { being economical should be followed. It is economical in terms of time } \\
\text { and effort. The topic is summarized. }\end{array}$ \\
\hline $\begin{array}{l}\text { 4.Providing } \\
\text { technological } \\
\text { information }\end{array}$ & 3 & $\begin{array}{l}\text { PST9. It helps the teacher to integrate technology into their lessons. It } \\
\text { develops the teacher's technological knowledge and their connection to } \\
\text { technology. }\end{array}$ \\
\hline $\begin{array}{l}\text { 5.Developing a } \\
\text { creative idea }\end{array}$ & 2 & $\begin{array}{l}\text { PST10. Most importantly, it helps the teacher develop creative ideas. } \\
\text { The teacher who makes in-depth research for the topic, to reflect } \\
\text { creative ideas in their story, makes the lesson more enjoyable. }\end{array}$ \\
\hline
\end{tabular}

When the opinions of primary school teaching candidates are taken into consideration, it is seen that the areas in which the use of digital story may contribute most to the primary school teachers are "facilitating narration" and "summarizing the topic". This can be considered to be that primary school teaching students envisage the use of digital stories to be a teaching strategy. Another contribution made by digital stories to primary school teachers is said to be, "providing technological information". In this context, it can be said that the integration of technology into lessons by primary school teachers who are able to use digital stories, will positively affect the their technological knowledge.

\section{Discussion and Conclusions}

In this study, digital stories created by the primary school teacher candidates were evaluated and their opinions on these digital stories were sought. In the research related to the use of digital story creation as a teaching tool, it was stated that it is an effective tool, strategy, or method, for the learning and teaching process of the " $Z$ " generation; that is, children who grow up with technology; it enables the students to develop skills, such as selfexpression, problem-solving, critical thinking and literacy and provides an opportunity for the students to create realistic products, organize their thoughts in a consistent way, and write creatively. (Ballast, Stephens \& Radcliffe, 2008; Belet \& Dal, 2010; Demirer, 2013; Doğan, 2007; Frazel, 2010; Gakhar, \& Thompson, 2007; Hung, Hwang \& Huang, 2012; Malita \& Martin, 2010; Ohler, 2013; Yang \& Wu, 2012). Also, it was argued that students who try to create digital stories learn to organize their ideas, ask questions that deepen their ideas and develop their communication skills through building their stories. Creating digital stories helps students to learn how to create stories for their audience and organize and present their ideas in a personal and meaningful way. Students who publish their digital stories online also have the opportunity to share their work with their peers. They acquire a valuable experience by critiquing their own stories and those created by others. In this respect, digital storytelling fosters collaboration between the students who are working in groups, and provide them with a sense of personal ownership and accomplishment (Robin, 2006).

In today's learning environments, how the content is presented is as important as the content itself. In today's culture, the sound of information is deafening and the challenge of attracting the students' attention requires communicating at the same frequency as that to which they listen. In this way, the digital story has become one of the most important teaching tools for reaching citizens of the digital age and linking them to the curriculum (Dreon, Kerper \& Landis, 2011). When a digital story is considered as a teaching tool, it will first attract the attention of the students, then by using technological facilities make them eager to learn, turning them into active participants in the projects that they internalize (Quigley, 2013). This is in parallel with the findings of the research. "Attracting attention" and "active engagement" are among the contributions made by primary school teaching students through the use of digital stories. İnceelli, (2005) has included these contributions in her definition of the digital story, in which she describes the story as a process that makes the user active by providing them with control over an interactive, digital environment, ensuring that they discover and create information on their own and use this information in real life situations, providing that the user forms the information in their mind in a meaningful way, while moving through the storyline. Sadik, (2008) claimed that digital story narration encourages the students to organize and express their opinions and knowledge in a personal and meaningful way. When they choose a personal story to work on, students have many opportunities to add a unique dimension to the story that is meaningful for themselves. 
Social sciences is a discipline mostly including topics regarding abstract concepts. In the social studies curriculum that came into effect in 2005 , which is based on a constructivist understanding, the approach focuses on active student engagement, decision-making, problem-solving and building their own information network (MONE, 2005). Digital stories have an important role to play in developing abstract thinking. Making stories, listening to stories and reading stories develop creative thoughts and provide lasting learning when combined with education. Also, multimedia applications appeal to multiple senses and by stimulating what is learnt through these multiple senses, make learning lasting (Turgut \& Kışla, 2015, Dupain \& Maguire, 2005; Bromberg, Techatassanasoontorn \& Andrade, 2013). This is shown by the results of the research. Primary school teaching students have reached a consensus that the use of digital stories in social studies teaching will make learning more lasting and that digital stories should be an effective and concrete teaching material that combine their inner worlds with the subject.

Digital storytelling, which is defined as a potent tool for the cognitive, affective and social development of the students, is also see as an effective tool for the teachers. It has a strategic role, particularly in conveying to the student a desired message about specific topics (Doğan, 2007). In their research, Smeda et al. (2014) created a constructive learning environment through digital story narration. In this context, an analysis was made of the impact made by digital story telling on the teacher and student during the learning process. When the opinions of teachers are sought, they stated that using digital story develops the technological skills of teachers, can be used as a complementary tool for teaching, increases use of technology in the classroom and can be used, in particular, in classes such as English, Social Sciences, History and Mathematics. The heart of creating a digital story is "writing the story", while "technology" should only be considered as a tool to create this story. Miller (2009) associated the extent to which technology is used to convey the digital story with the teachers' perspective on technology. It has always been hard for the teachers to integrate technology into their lessons because teachers doubt their own technological skills. Teachers who play with technology more will benefit more from the digital story narration process. Moreover, in this process, the teacher who is connected to technology will have better technological knowledge. Primary school teaching students have claimed that use of digital story in the research process helps the teacher with regards to "providing technological information". In this regard, it can be said that the research results are similar. According to Robin (2006), teachers who create digital stories in their lessons use discussion and narration as an enabling tool, based on the titles of the digital stories, to summarize the lesson content, or to make the concepts more comprehensible. Göçen (2014) reached the conclusion that, following the use of the digital storytelling method, learning and studying strategies of the test group were more effective than teaching using PowerPoint, and has stated in her research that teachers are able to use digital stories to summarize, integrate, evaluate, provide feedback for the subject, as well as to correct and remotivate. When the opinions of primary school teaching candidates are taken into consideration, it can be seen that the areas in which the use of digital story may contribute to the primary school teachers are "facilitating narration" and the "effective use of learning time". This can be considered to be that primary school teaching students envisage the use of digital stories to be a teaching strategy.

Using a digital story is a creative process, since it combines traditional stories with audio recording, editing, tha use of a video camera and individual digital technologies using a PC (Ohler, 2013). The objectives of studies by Yüksel, Robin \& McNeil (2011) was to show to the world the use of digital story narration for educational purposes. In line with this, data were acquired from educators around the world who use digital stories, with the perception of the use of digital stories in the classroom, personal use, and the accessibility of technology through education and support. According to the findings, some of the participants claimed that digital stories help to develop a higher order of thinking skills by the students and this was defined by some of the participants, as creative thinking skills. While some research includes findings suggesting that digital stories increase creative thinking skills, some have defined digital stories as an effective and successful tool to attract the attention of students to the lesson, which can be easily integrated with technology (Robin, 2008; Stanley and Dillingham, 2009; Pelayo, 2013). According to the findings of this research, it was proposed that the use of digital stories will encourage primary school teachers to develop creative ideas.

The objectives of studies by Yüksel et al. (2011) was to show to the world the use of digital story narration for educational purposes. In line with this, data were acquired from educators around the world who use digital stories, with the perception of the use of digital stories in the classroom, personal use, and the accessibility of technology through education and support. At the end of the research, participants stated that they needed computer support for software and hardware during the process of creating a digital story, a better visual and audio equipment, as well as appropriate computer software that combines video and audio. In the findings of the study by Baki (2015), entitled, Impact of Digital Stories on the Writing Process of Sixth Grade Students, it was claimed that female participants mostly faced difficulties during the process of creating a digital story in story writing (52.94\%) and writing using Word (47.05\%); while male participants have most problems in visualization $(53.84 \%)$ and story writing $(30.76 \%)$ and all participants faced problems with story writing (43.33\%) and visualization (33.33\%). Yamaç (2015) conducted a study the objective of which was to show the 
impact of digital stories on the development of writing skills of primary school third grade students studying in rural areas. The findings of this study included the difficulties students faced during the process of creating a digital story. Accordingly, the foci of the difficulties encountered was presented under four sub-headings, including implementation-related difficulties, lack of equipment, student-related difficulties and Internet-related difficulties. The sub-themes of the story creation, taking a long time, the lack of a PC, negative sense of competence and problems with Internet connectivity stand out amongst these themes. Karakoyun (2014) studied the opinions of teacher candidates and students during the implementation of online digital storytelling activities by teacher candidates for primary school students. The results of this research included issues relating to processes, such as the uncertainty of the students about the safety of their Internet data during digital storytelling, not having access to sufficient resources relating to the topic that were being researched and the technical problems that were encountered.

This study was based on the opinions of students studying at a department of primary school teaching and the evaluation of the stories they created at the end of the digital story teaching process, so that they were able to conduct their social sciences lesson at an increased level of quality. In order to actively mirror these studies on the teaching process, digital storytelling studies can be used in various lessons by primary school teachers or teaching candidates studying in other departments. In this way, the use of technology in education will be expanded. By preparing their own creative teaching materials, today's students, who are seen as the digital generation, will have lasting learning with this method. Also, the teacher profile that the teacher candidate will present in the future, by means of the digital stories that were created, can be considered to encourage the growth of a digital generation.

\section{References}

Akkoyunlu, B. (2002). Educational technology in Turkey: past, present and future. Educational Media International, 39(2), 165-174.

Alexander, B. (2011). The new digital storytelling: The creating narratives with new media. ABC-CLIO. Greenwood publishing group.

Baki, Y. (2015). The Effect of Digital Stories on the Sixth Grade Students' Writing Process. (Doctoral dissertation). Erzurum: Atatürk University Institute of Educational Sciences.

Ballast, K., Stephens, L. \& Radcliffe, R. (2008). The Effects of Digital Storytelling on Sixth Grade Students' Writing and Their Attitudes about Writing. In K. McFerrin, R. Weber, R. Carlsen \& D. Willis (Eds.), Proceedings of Society for Information Technology \& Teacher Education International Conference (pp. 875-879). Chesapeake, VA: Association for the Advancement of Computing in Education (AACE).

Barrett, H. (2006). Researching and evaluating digital storytelling as a deep learning tool. In C. Caroline, D.A., Willis, R. Carlsen, I. Gibson, K. McFerrin, J. Price \& S. Weber (Ed.), Society for Information Technology and Teacher Education International Conference (pp. 647-654). Chesapeake, Virginia, AACE.

Barrett (2010) The educational uses of digital storytelling. University of Houston [Online]. Available: http://digitalstorytelling.coe.uh.edu/archive/rubrics.html (15February, 2015)

Belet, S. D., \& Dal, S. (2010). The use of storytelling to develop the primary school students' critical reading skill: The primary education pre-service teachers' opinions (pp. 1830-1834). Procedia Social and Behavioral Sciences. doi:10.1016/j.sbspro.2010.12.409.

Bromberg, N. R., Techatassanasoontorn, A. A. ve Andrade, A. D. (2013). Engaging Students: Digital Storytelling in Information Systems Learning. Pasific Asia Journal of the Association for Information Systems, 5 (1), 1-22.

Büyüköztürk, Ş., Kılıç- Çakmak, E.,Akgün, Ö. E., Karadeniz, Ş. \& Demirel, F. (2010). Örnekleme Yöntemleri, In Büyüköztürk, Ş. (Ed.), Bilimsel Araştırma Yöntemleri, (pp. 77-100) Ankara: PegemA Publishing.

Chung, S. K. (2007). Art education technology: Digital storytelling. Art Education, 60 (2), 17- 22.

Demirer, V. (2013). Use of e-storytelling in primary education and its effects. (Doctoral dissertation), Konya: Necmettin Erbakan University Institute of Educational Sciences.

Di Blas, N., Garzotto, F., Paolini, P., \& Sabiescu, A. (2009). Digital storytelling as a whole-class learning activity: Lessons from a three-years project. In Iurgel, I. A.; Zagalo, N. \& Petta, P. (Ed.), Interactive Storytelling (pp. 14-25). Springer Berlin Heidelberg.

Doğan, B. (2007). Implementation of digital storytelling in the classroom by teachers trained in a digital storytelling workshop (Doctoral dissertation), Houston: University of Houston.

Dreon, O., Kerper, R. M., \& Landis, J. (2011). Digital storytelling: A tool for teaching and learning in the YouTube generation. Middle School Journal, 42(5), 4-10.

Dupain, M., \& Maguire, L. (2005). Digital story book projects 101: How to create and implement digital storytelling into your curriculum. In $21^{\text {st }}$ Annual Conference on Distance Teaching and Learning. (pp.1- 
4).

Frazel, M. (2010). Digital storytelling guide for educators. Washington, DC: International Society for Technology in Education.

Gakhar, S., \& Thompson, A. (2007). Digital storytelling: Engaging, communicating, and collaborating. In Society for Information Technology \& Teacher Education International Conference. 2007 (1), 607612.

Gakhar, S. \& Thompson, A. (2007). Digital Storytelling: Engaging, Communicating, and Collaborating. In R. Carlsen, K. McFerrin, J. Price, R. Weber \& D. Willis (Eds.), Proceedings of Society for Information Technology \& Teacher Education International Conference 2007 (pp. 607-612). Chesapeake, VA: Association for the Advancement of Computing in Education (AACE).

Göçen, G. (2014). The effect of digital storytelling method on students' academic achievement and learning and study strategies. (Master's Thesis), Muğla: Muğla Sitk1 Koçman University Institute of Educational Sciences.

Güzel, E. B., \& Uğurel, I. (2010). The relationship between pre-service mathematics teachers' academic achievements in calculus and their mathematical modelling approaches. Ondokuzmayis University Journal of Education, 29(1), 69-90.

Hays P. A. (2004). Case study research. In K. deMarrais \& S. D. Lapan (Eds.) Foundations for research: Methods of inquiry in education and the social sciences (pp. 218-234). LEA Publishing.

Hess, M. E. (2014). A new culture of learning: Digital storytelling and faith formation. Dialog: A Journal of Theology, 53(1), 12-22. Doi: 10.1111/dial.12084.

Hull, G. A. (2003). At last: Youth culture and digital media: New literacies for new times. Research in the Teaching of English, 38(2), 229-233.

Hung, C. M., Hwang, G. J., \& Huang, I. (2012). A project-based digital storytelling approach for 1mproving students' learning motivation, problem-solving competence and learning achievement. Educational Technology \& Society, 15(4), 368-379.

İnceelli, A. (2005). Dijital hikâye anlatımının bileşenleri. Turkish Online Journal of Educational Technology, $4(3), 132-142$

Karakoyun, F. (2014). Examining the views of elementary school students and preservice teachers about digital storytelling activities in online environment (Doctoral Dissertation), Eskişehir: Anadolu University Institute of Educational Sciences.

Kurudayığlu, M., \& Bal, M. (2014). Ana dili eğitiminde dijital hikâye anlatımlarının kullanımı. Sakarya Üniversitesi Ĕ̌itim Fakültesi Dergisi, 28, 77-99.

Quigley, S. (2013). Digital Storytelling: Through the Eyes of Others. In C. Sistek (Eds.) [Online]. Available: https://my-ecoach.com/project.php?id=14399 (March 2, 2016)

Malita, L., \& Martin, C. (2010). Digital storytelling as web passport to success in the 21st century. ProcediaSocial and Behavioral Sciences, 2(2), 3060-3064. doi:10.1016/j.sbspro.2010.03.465.

Miller, E. A. (2009). Digital storytelling. (master's thesis). University of Northern Iowa, USA. [Online]. Available: http://www.uni.edu/icss/researchhelps/miller.pdf. (January 13 2016)

MONE, (2005) Ilköğretim Sosyal Bilgiler Dersi Öğretim Programı ve Kılavuzu (4. ve 5. sinıflar) [Online]. Available: http://ttkb.meb.gov.tr/www/ogretim-programlari/icerik/72. (March 8, 2015)

Morgan, H. (2014). Using digital story projects to help students improve in reading and writing. Reading Improvement, 51(1), 20-26.

Ohler, J. B. (2013). Digital storytelling in the classroom: New media pathways to literacy, learning, and creativity. Corwin Press.

Pelayo, M. G. (2013). The making of digital storytelling as a tool for promoting the learning process in the classroom. European Scientific Journal. 8(2), 463-466.

Prensky, M. (2001). Digital Natives, "Digital Immigrants, Part II: Do They Really Think Differently?" On the Horizon, 9(6), 1-6.

Robin, B. (2006). The educational uses of digital storytelling. In C. Crawford, R. Carlsen, K. McFerrin, J. Price, R. Weber \& D. Willis (Eds.), Proceedings of Society for Information Technology \& Teacher Education International Conference, (pp. 709-716). Chesapeake, VA: Association for the Advancement of Computing in Education (AACE).

Robin, B. R. (2008). Digital storytelling: A powerful technology tool for the 21 st century classroom. Theory Into Practice, 47(3), 220-228. doi:10.1080/00405840802153916.

Sadik, A. (2008). Digital storytelling: A meaningful technology-integrated approach for engaged student learning. Educational Technology Research and Development, 56, 487-506. Doi: 10.1007/s11423-0089091-8, http://classroomweb20.pbworks.com/f/digital+storytelling.pdf.

Smeda, N., Dakich, E., \& Sharda, N. (2014). The effectiveness of digital storytelling in the classrooms: A comprehensive study. Smart Learning Environments, 1(6), 1-21. Doi: 10.1186/s40561-014-0006-3, 
http://www.slejournal.com/content/1/1/6.

Stanley, N., \& Dillingham, B. (2009). Performance literacy through storytelling. Maupin House Publishing, Inc..

Sylvester, R., \& Greenidge, W. (2009). Digital storytelling: extending the potential for struggling writers: digital technologies can motivate struggling writers and scaffold understanding of traditional literacy. The Reading Teacher, 63 (4), 284-295. Doi: 10.1598/RT.63.4.3.

Şencan, H. (2005). Sosyal ve davranışsal ölçümlerde Güvenilirlik ve Geçerlilik. Ankara: Seçkin publishing.

Turgut, G. \& Kışla, T. (2015), The use of computer-aided story in education: Literature review. Turkish Online Journal of Qualitative Inquiry, April 2015, 6(2), 97-121.

Ware, P., \& Warschauer, M. (2005). Hybrid literacy texts and practices in technology-intensive environments. International Journal of Educational Research, 43(7-8), 432-455.

Yamaç, A. (2015) The effect of digital storytelling in improving the writing skills of third grade school students. (Doctoral dissertation). Ankara: Gazi University Institute of Educational Sciences.

Yang, Y. T. C., \& Wu, W. C. I. (2012). Digital storytelling for enhancing student academic achievement, critical thinking, and learning motivation: A year-long experimental study. Computers \& Education, 59(2), 339-352.

Yüksel, P. (2011). Using digital storytelling in early childhood education a phenomenological study of teachers' experiences. (Doctoral dissertation). Ankara: Middle East Technical University Institute of Educational Sciences.

Yüksel, P., Robin, B. R. \& McNeil, S. (2011). Educational Uses of Digital Storytelling Around the World . [Online]. Available: http://editlib.org/p/36461/ (January 11, 2016) 